\title{
FIGURATIVE LANGUAGE IN EVANESCENCE'S ALBUM ANYWHERE BUT HOME
}

\author{
Sumarno, Purwarno, M. Manugeren \\ Master's Program, Fakultas Sastra, \\ Universitas Islam Sumatera Utara, Medan, Indonesia \\ Corresponding author: habsi.madani@gmail.com
}

\begin{abstract}
The research deals with figurative language, aimed to identify the types and interpret the ideas or messages implicitly or explicitly expressed with theoretical based proposed by Kennedy and Giola (2005) that figurative language is an expression of comparison that relies not on its literal meaning, but rather on its connotations. Figurative language is also commonly used in song lyrics and this is referred to as the object of the research, that is the song lyrics taken Evanescence's album Anywhere but Home. This album consists of five songs: Everybody's Fool, Going under, Haunted, Taking over Me and Thoughtless. Qualitative content analysis as the use of replicable and valid method for making specific inferences from text to other states or properties of its source under Descriptive Qualitative Approach, pioneered by Krippendorff (2000) is applied here. The results show that Hyperbole, Repetition, Personification, Metaphor, Erotesis, Merism, referring to Kosasih's category of figurative language are found in the song album with various meanings. (2007)
\end{abstract}

Key words: figurative language, song, lyrics

\section{Introduction}

Figurative language is a language that one must figure out. The term "figurative" is an antonym of "literal." In literal language the words convey meaning exactly as defined, whereas in figurative language there is room for interpretation. An effort is required on the part of the interpreter to determine the speaker or writer's intended meaning. The listener or reader must "figure" out what is meant.

To understand what figurative language is, it is important to start with a working definition of literal language. Literal language refers to a phrase or sentence that is to be taken at face value to mean exactly what it says. For example, if a sentence reads, "he went outside the box," that means the man was in a box and went outside of that area to another space. Figurative language means using words to imply another meaning or to evoke an emotion. Going back to the previous example, "he went outside the box," the sentence would have a whole different meaning if taken figuratively. By interpreting, "he went outside the box," figuratively, the sentence means that the person used his imagination and creativity to solve a problem. So, the same sentence can have completely different meanings when taken either literally or figuratively. 
This begs the question of how a person knows when to take a sentence to be literal or figurative. The key to understanding whether a phrase needs to be taken literally or figuratively is a common sense. Connotation refers to how the words and sentences preceding or following the phrase in question help to place the phrase into the correct context. For example, in the example sentence, "he went outside the box," if the preceding sentences explains that a man was trapped inside of a box or perhaps referred to a baseball batter's box, the reader would take that into consideration and know that the sentence should be taken literally to mean that the man actually stepped outside of a box. If however, the sentences and words around the phrase talked about the man trying to solve a problem or using his creativity or imagination to some purpose, the phrase can and should be taken figuratively to mean that he solved a problem with unconventional means and thinking. Using a little common sense gained from life experiences can help the reader to understand the difference between a literal meaning and a figurative one, also Figurative language also includes terms like simile, metaphor, personification, and so on, but the root of the problem remains the same -figuring out the meaning of the phrase through context and connotation. By using figurative language, writers can evoke emotion and imagery from their writing that literal language just cannot provide. By doing so, figurative language makes expressing meaning through writing easier and more relatable to the reader.

Figurative language has been widely examined by linguists in the study of literature in recent years. It is because figurative language has the essence of style and beauty. In its ordinary acceptation, the word figurative, when applied to written or spoken language, refers merely to certain picturesque modes of expressing our idea. Figurative language often provides a more effective means of saying what we mean than direct statement

Figurative language is word/s or groups of words used to give particular emphasis to an idea or sentiment. Figurative language expresses an idea or experience vividly, forcefully, and briefly. Sometimes figurative language may seem even more direct than literal language because it helps the listener grasp important ideas immediately.

In other words, figurative language is a form of expression in which words are used differently from their normal meanings. According to James (2009: 65) figurative language is a form of expression that departs from normal word or sentence order or from common literal meanings for words, for the purpose of achieving a special effect.

In broad outline, figurative language can be divided into four kinds. David (2015:8), states that figures thus consist of two great classes, those that lie in an artificial use of words for the purpose of more convenient or emphatic expression, and those that lie in an artificial use of things for that purpose, or for illustration and ornament. To the former belong the metaphor, metonymy, synecdoche, hyperbole, personification, and the apostrophe; to latter the comparison, the hypo-catastasis, and allegory.

Figurative language is not only found in poetry, but also found in other arts such as in music. There are several types of music, such as jazz, rock, pop, and others. Every kind of music must be a beautiful work of art usually modified by figurative language. There 
are beautiful lyrics in a song and can give the impression of a separate message to the audience and singer.

Figurative language can also be used in lyrics of the music or lyrics of a song, in a lyric sometimes there are some types of figurative language and the songwriter might just want to convey the message in the song. It will feel more beautiful when a song creator inserts the figurative language in song. This is what will be peeled in this research, a study on figurative language through the songs taken from an album by "Evanescence" - "Anywhere but Home".

\section{Literature Review \\ Songs}

In music, a song is a composition of voice or voices, performed by singing or alongside with musical instruments. A choral or vocal song may be accompanied by musical instruments, or it may be unaccompanied, as in the case of a cappella songs. The lyrics (words) of songs are typically of a poetic, rhyming nature, though they may be religious verses or free prose. A song may be for a solo singer, a duet, trio, or larger ensemble involving more voices. Songs with more than one voice to a part are considered choral works. Songs can be broadly divided into many different forms, depending on the criteria used. One division is between "art songs", "pop songs", and "folk songs". Other common methods of classification are by purpose (sacred vs secular).

A song is certainly one of the most prominent elements in music. People will come across several different categories of songs which have a unique mood and touch. As a result, they cannot be differentiated on the basis of specific factors. The main reason why songs cannot be marked in only one class is because the differences in their type of music, lyrics, and purpose. (Bronson, 2010)

\section{Figurative Language}

Language offers many ways or alternatives in expressing idea, feelings, messages, and so on. It is assumed that a boy is falling in love with a girl, and says," here is true love stands in my heart, Baby!" then she replies, "I can feel it through your eyes". If one figures out or examine this conversation one will find a language is spoken out figuratively. It is clear enough to say that the sentence expresses something more than literal meaning of the words.

Figurative language is where a word or words are used to create an effect, often where they do not have their original or literal meaning. If someone says that they are 'starving', they do not mean that they are in fact dying of hunger, but that they are very hungry. This is a simple example of a figurative language, where the word is used to heighten or increase the state that they are describing. The figurative language is usually analyzed by applying stylistics.

Figurative language is the language, on the whole favored by rhetoricians, poets, fiction writer, and the like. Figurative language is said to be the language that speaks 
symbolically. The terms are then unplaced to mean language symbol: the act of speaking in "language symbol".

Perrine (2000: 34) states that first figurative language affords readers imaginative pleasure of literary works. Second, it is a way of bringing additional imagery into verse, making the abstract concrete, making literary works more sensuous. The third, figurative is a way of adding emotional intensity to otherwise merely informative statements and conveying attitudes along with information. And the last, it is a way of saying much in brief compass. She divides figurative language into seven types, namely metaphor, simile, personification, metonymy, paradox, overstatement, understatement, irony and illusion.

According to Kennedy and Giola (2005: 6), figurative language is an expression of comparison that relies not on its literal meaning, but rather on its connotations. Figurative language is an expression, as a metaphor, simile, personification, hyperbole, using words in a non-literal sense or unusual manner to add vividness, beauty, etc to what is said or written.

In broad outline, figurative language can be divided into four kinds (Kosasih, 2007: 121): Comparison, Substitution, Addition or amplification, Omission or suppression

Table 1. Classification of the Figurative Language

\begin{tabular}{|l|l|l|}
\hline No & Division of Figurative Language & Subdivision of Figurative Language \\
\hline 1 & Comparison & Simile, methapor, allegory, and personification \\
\hline 2 & Substitution & Metonymy, synecdhoce, merism, euphemism, and irony \\
\hline 3 & Addition or amplification & Parallelism, repetition, hyperbole, climax, and anticlimax \\
\hline 4 & Omission or suppression & Ellipsis, erotesis, and meiosis \\
\hline
\end{tabular}

From those several definitions, it can be concluded that figurative language is the use of language in non - literal meaning. It is aimed at making the listener more interested in the content of lyrics.

In the figurative language the author transfers a word into a foreign semantic field to illustrate or picture a thought and to evoke the appropriate feeling of the reader. In this way it shows a comparison between two things of unlike nature that yet have something in common. The subject matter is real, but that to which it is compared is present in the imagination. That which the subject and things compared have in common is not stated and must be guessed at and validated by the interpreter from other indications in the composition. The interpreter must also try to articulate the mood evoked by the figure.

\section{Simile}

Simile is a resemblance, an explicit comparison (using "like" or "as") between two things of unlike nature that yet have something in common. For example: He was as angry as a bull at a red flag. It means that if someone is angry, he is like a bull at a red flag, his face is red and he seems to pounce everything. 


\section{Metaphor}

A metaphor is an analogy between two objects or ideas, conveyed by the use of a word instead of another (Davidson, 2008:89). This description will serve the purpose of this introduction, but it must be acknowledged to be simplified. Pure metaphors are essentially figures of transference.

Like similes, metaphors can be either implicit or explicit in nature. An implicit metaphor is a metaphor in which the characteristic being compared between two objects is not stated and left up to the reader to imply the meaning from the context of the sentence. The previous example is an example of an implicit metaphor in which the reader has to make the inference that the house is hot. For an implied metaphor, a reader has to draw upon their own experiences to make the connection. A metaphor is explicit if the characteristic being compared is stated.

\section{Allegory}

Expositors often say that an allegory refers to something non - historical in the comparison, but this may be more apologetic than factual. In the classical sense an allegory is an extended metaphor, the thing used in the comparison could be historical or

\section{Personification}

Personification is the investment of non - human qualities or abilities, with all the figure involving resemblance. The things compared are of unlike nature, but the thing to which the comparison is made is always a person. The figure is used to stir emotions and to create an empathy with the subject. For example: "The land mourns the oil languishes". The human traits of morning and languishing are attributed to the land, thus making a comparison. But the thought is the extreme agricultural disaster, and the feeling is sadness or grief.

\section{Metonymy}

Metonymy is a figurative language used in rhetoric in which a thing or concept is not called by its own name, but by the name of something intimately associate with that thing or concept (Kosasih:2007:122). In this figure change of noun or any idea, the change of a word naming an object for another word closely associated with it. a metonymy can word with a verb as well, or a whole line. The substitution of some attributive or suggestive word for what is it meant.

\section{Synecdoche}

Synecdoche is an exchange of one idea for another connected idea. In this figure on word receives something from another which is unexpressed but associated with it because it belongs to same genus. Like metonymy the figures is based on a relationship rather than a resemblance. But whereas in metonymy the exchange may be made between related words belonging to different genera (and so only loosely connected by contact or ascription). In synechdoche the exchange is made between two words related generically. For example, "ends of earth" as a metonymy of subject would mean 
the people living in the ends of earth, but as a synecdoche it would mean distant geographical locations as part of larger mass of land - soil, not people.

\section{Merism}

Merism is a figurative language by which a single thing is referred to conventional phrase that enumerates several of its parts, or which lists several synonyms for the same thing. The use of two opposite statements to signify the whole; example: day and night, spring time and harvest, hell and high water.

\section{Euphemism}

The term euphemism refers to polite, indirect expressions which replace words and phrases considered harsh and impolite or suggest something unpleasant.

\section{Irony}

Irony is a figurative language in which words are used in such a way that their intended meaning is different from the actual meaning of the words. It may also be a situation that may end up in quite a different way than what is generally anticipated.

\section{Parallelism}

Refers to the use of grammatically equal elements in sentences and paragraphs. We may view parallelism as a matter of balance. When elements are balanced (parallel), the result is clear and smooth; when they are not balanced, the result is awkward confusing. Parallelism examples are found in literary works as well as in ordinary conversations.

\section{Repetition}

Repetition is the repeating of a phrase, word or stanza form. It is a strong literary device used for emphasizing something important. It can also help tie different ideas together. Repetition is an effective literary device that may bring comfort, suggest order, or add special meaning to a piece of literature.

\section{Hyperbole}

Hyperbole, derived from Greek word meaning "over-casting" is a figurative language, which involves an exaggeration of ideas for the sake of emphasis.

\section{Climax}

Climax, a Greek term meaning "ladder", is that is that particular point in a narrative at which the conflict or tension hits the highest point.

\section{Erotesis}

Erotesis comprises fictional and factual stories and accounts of human sexual relationships which have the power to or are intended to arouse the reader sexually.

\section{Research Method}

This research is done by qualitative content analysis embedding the song album of Evanescence "Anywhere but Home" showing the aims of the discussion. This is 
expressed by Krippendorff (2000), defining content analysis as the use of replicable and valid method for making specific inferences from text to other states or properties of its source under Descriptive Qualitative Approach. The data in this research are taken from the album by Evanescence group, Anywhere but Home. The sources of the data are the lyrics of the five songs in the album. Other respective sources are also take to support the research.

\section{Discussion}

This album consists of five songs: Everybody's Fool, Going under, Haunted, Taking over Me and Thoughtless. Everybody's Fool talks about fake people pretending to be what they are not just to be accepted and loved in society. Going under talks about a bad relationship; Haunted song about someone who has been out for a while, but the person will return because of being haunted in dreams; Taking over me about someone who always remembers God. Thoughtless about people being constantly ridiculed.

\section{Song 1: Going Under}

In this song there are four expressions of figurative language

\section{50 thousand tears l've cried}

In the lyric above, the figure is hyperbole. The hyperbole is an exhibition of things greater or less in dimension, more or less in number. Hyperbole is to give the impression in every word. The meaning of the word above shows that the author of the song gives the impression of exaggeration, the authors over-dramatizes the situation. It means that the author is very sad, depressed and $\mathrm{s} /$ he has cried for so long on this matter to show her/his sadness.

\section{Just when I thought I had reached the bottom I am dive again.}

In the lyric above, the figure is hyperbole. The hyperbole is an exhibition of things greater or less in dimension, more or less in number. hyperbole is to give the impression in every word. Hyperbole, like other figurative language, is used to communicate ideas, emotions, and images in a more efficient way than through plain language. It means that the author uses exaggerated words, when a person dives just because she has reached the bottom.

\section{I'm falling forever}

In the lyric above, the figure is hyperbole. The hyperbole is an exhibition of things greater or less in dimension, more or less in number. hyperbole is to give the impression in every word. Hyperbole, like other figurative language, is used to communicate ideas, emotions, and images in a more efficient way than through plain language. It means that the author is very sad so that the author feesl she/he cannot give up from sadness. The author is in depression.

\section{Blurring and stirring the truth and the lies}

In the lyric above, the figure is hyperbole. The hyperbole is an exhibition of things greater or less in dimension, more or less in number. Hyperbole is to give the impression in every word. Hyperbole, like figurative language, is used to communicate ideas, emotions, and images in a more efficient way than through plain language. The meaning of the word above shows that the author uses exaggerated words and actually the author really wants to say that the truth and the lies become one, but in this song, 
the author uses figurative language to add the sense. So that she/he adds word blurring and stirring to be more interesting.

\section{Song 2: Everybody's fool}

This song has two types of figurative language:

\section{Bow down and stare in wonder}

In the lyric above, the figure is merism. Merism is a figurative language by which a single thing is referred to as a conventional phrase that enumerates several of its parts, or which lists several synonyms for the same thing. It means that, the author combines two different words of opposite meaning. Bow down and stare. If one bows down, certainly, one sees down and not stare in wonder.

\section{Can't find yourself, lost in your lies}

In the lyric above, the figure is metaphor. A metaphor is an analogy between two objects or ideas, conveyed by the use of a word instead of another. It means that, the author wants to say that someone cannot lose with her/his lie, because if someone is to be a liar, some people cannot believe or trust what the person says.

\section{Song 3: Haunted}

In the lyric above, there are two types of figurative language:

\section{Long lost words whisper slowly to me}

In the lyric above, the figure is personification. Personification is a figurative language in which a thing, an animal or an abstract term (truth, nature) is made. It means that, the words cannot whisper, but mouth of human gets the result of soft sound as a whisper is a human mouth activity.

\section{You heart pounding in my head}

In the lyric above, the figure is metaphor. A metaphor is an analogy between two objects or ideas, conveyed by the use of a word instead of another. It means that usually heart is in the body and it is near the chest, but if the heart is pounding the chest is pounded too; but in the lyric above the author's head is pounding.

\section{Song 4: Taking over me}

In the lyric above, there are two types of figurative language:

1. If I look deep enough So many things inside that are just like you are taking over In the lyric above, the figure is simile. Simile is a resemblance, an expilcit comparison (using "like" or "as") between two things of unlike nature that yet have something in common. It means that the author describes the things is like someone who want to take over.

\section{You don't remember me but I remember you}

In the lyric above, the figure is repetition. Repetition is the repeating of a phrase, word or stanza form. The author makes the repetition to make emphasis of meaning.

\section{Song 5: Thoughtless}

In the lyric above, there are five types of figurative language:

\section{Pushing all the mercy down, down, down}

In the lyric above, the figure is repetition. Repetition is the repeating of a phrase, word or stanza form. The author makes the repetition to make emphasis of meaning. 


\section{Thumbing through the pages of my fantasies}

In the lyric above, the figure is hyperbole. The hyperbole is an exhibition of things greater or less in dimension, more or less in number. Hyperbole is to give the impression in every word. It means that the author uses overlapping words to make the sense more interesting, and then the author wants to say that the feeling is not good, because the mind is not focused.

\section{Come on, gonna put you on the ground, ground, ground}

In the lyric above, the figure is repetition. Repetition is the repeating of a phrase, word or stanza form. The author makes the repetition to make emphasis of meaning.

\section{I want you crying when you're dirty ass in front of me}

In the lyric above, the figure is erotesis. Erotesis comprises fictional and factual stories and accounts of human sexual relationships which have the power to or are intended to arouse the reader sexually.

\section{I wanna kill and rape you the way you raped me}

In the lyric above, the figure is erotesis. Erotesis comprises fictional and factual stories and accounts of human sexual relationships which have the power to or are intended to arouse the reader sexually.

\section{Conclusions}

Table 2. Frequency Figurative Language on album song of Evanescence

\begin{tabular}{|c|l|c|}
\hline No & Figurative Language & Frequency \\
\hline 1 & Hyperbole & 5 \\
\hline 2 & Repetition & 3 \\
\hline 3 & Personification & 1 \\
\hline 4 & Metaphor & 2 \\
\hline 5 & Erotesis & 2 \\
\hline 6 & Merism & 1 \\
\hline
\end{tabular}

The above chart is the result of the analysis presented in the form of finding. In short it is seen that the song album of Evanesces contains several types of figurative language, all of which have been analyzed in details. Out of many figurative languages commonly used in various context, there are six types found: Hyperbole, Repetition, Personification, Metaphor, Erotesis and Merism. The most dominant of figurative language in the song album is Hyperbole, numbered to 5.

\section{References}

Bronson, Bertrand Harris. (2010). The Ballad As Song. Berkely: California University David, N. Lord. (2015). Charateristics of Figurative Language. New York: Franklin Knight Davidson. Donald. (2008). "What Methapors Mean". Reprinted in Inquires into Truth and Interpretation. Oxford: Oxford University Press.

James, Michael. W. (2009). Style, Rhetoric, and Rhythm. New York: Princeton Kennedy, X. J. and Gioia. 2005. Introduction to Poetry. New York: Longman Kosasih, 2007. Bimbingan Pemantapan Bahasa Indonesia. Bandung: Obor.

Perrine, L. (2000). Sound and Sense. An Introduction to Poetry. Sixth Addition. Harcourt: Brave Jovanovich. 